\title{
Panel analysis on the changes in the quality of life of the divorced elderly
}

*Yun-Jeong Kim, Dept. of Health, Counseling and Welfare, Hanseo University, 46, Hanseo 1-ro, Haemi-Myun, Seosan-Si, Chungcheognam-do, 31962, Republic of Korea, twoyun21@hanamil.net

\begin{abstract}
In this study, a panel analysis was conducted by combining the 2013 Korea Welfare Panel data and 2018 data to examine the differences in the quality of life of the divorced elderly and the difference between the married elderly. To this end, I analyzed data from 3,049 married elderly and 149 divorced seniors among 3,098 married persons over 60 years of age in the eighth Wave of Korea Welfare Panel 2013. The frequency, reliability, cross tab, paired t-test and analysis of covariance (ANCOVA) were performed using SPSS 21.0. First, the change in marital status of the elderly was not significant. Second, the divorced elderly were adjusting to life after divorce. In other words, income satisfaction, family relationship satisfaction, child relationship satisfaction, leisure life satisfaction, and life satisfaction were all positively changed in 2018 compared to 2013. Third, the divorced elderly had a lower quality of life compared to the married elderly. In other words, despite the positive change in quality of life for five years after divorce, the income satisfaction, family relationship satisfaction, child relationship satisfaction, social relationship satisfaction, and leisure life satisfaction were all lower than those of married elderly people were. It is important to find ways to improve the quality of life after divorce. Efforts are needed to reduce negative social perceptions about divorce in old age. And, alternative family linkages are needed.
\end{abstract}

Keywords: Panel study; Divorced elderly; Changes and difference in the quality of life; Ancova; Korea Welfare Panel data.

Received: 07.12.2020 $\quad$ Accepted: $10.01 .2021 \quad$ Published: 05.02.2021

\section{INTRODUCTION}

In recent years, the term twilight divorce has frequently appeared in Korea. However, twilight divorce is a social term rather than a legal institutional term. Twilight divorce is a new word that originated in the early 1990s. When the Japanese economy entered a recession, Korean media reported that the number of salaried people who filed a divorce lawsuit from their wives after taking severance payments began to appear (Lee HS, 2018). In the sense of consultation, it is synonymous with divorce in old age after the $60 \mathrm{~s}$ to $70 \mathrm{~s}$, but in the broadest sense, it means divorce after the children became independent or became independent as college students, or the divorce of a couple who has been married for 20 years or more . The number of old age divorces in Korea tends to increase every year. Among the total divorces in Korea, married couples divorced more than 20 years, 33.4\%, up 9.7\% year-on-year. This is considerably higher than the increase in the total number of divorces by $2.5 \%$, contrary to the diminishing divorces of other ages (Kostat a, 2019).

Reasons for the increase in old age divorce, first, the opinion of the elderly divorced was somewhat positive. Second, the baby boomers entered the elderly and the population itself grew. Third, because of the prolonged lifespan, old age was extended. Therefore, the purpose of this study is to focus on how their quality of life will be in the midst of divorce due to the change in opinion on divorce, the growth of the middle-aged population, and the longevity of humanity. In particular, from a longitudinal perspective, this study focused on how the quality of life after divorce will change.

Looking at previous studies related to divorce, divorce can ruin the quality of life of old age. In other words, divorced people experience more health problems (Lillard A et al., 1995; Zick D et al., 1991), and divorced men have higher suicide rates, lower levels of happiness, and higher depression than married men (Kostat a, 2019). The economic difficulties after divorce are common (Andreevna S., 2015), this is also because they tend to decide on divorce when economic conditions are difficult (Hetherington $\mathrm{M}$ et al., 2002). But especially for women, it is extremely difficult for women outside the marriage system to recover economically again [Morgan, 1991]. Social relations are also difficult. Divorced women feel limited in their relationships with others and experience discrimination and alienation in their relationships with others because of the stigma of divorce that still exists in society (Kitson C et al., 1990). 
Although elderly divorce is on the rise, only a few studies have been conducted on the elderly. A study on the increase and characteristics of old age divorce at the social level (Park H etal., 2013 ; Anuara H et al., 2019), a study on the effect of divorce intentions on elderly couples (Jo YS, 2014), and Korea-Japan comparison. Adaptation studies of divorced males (Lee HS., 2018). As a qualitative research method, there is a study dealing with adaptation after divorce (Lee H S., 2015; Moon J H et al., 2014).

However, these previous studies, firstly, do not reveal the level of adaptation after divorce through 'change' of quality of life as a limitation of cross-sectional design. Secondly, studies mainly on divorced people lack information on whether the quality of life of a divorced elderly person is lower than that of a married person. Finally, there are limitations in identifying the substance of divorce mainly by studying divorce intention or by using qualitative research methods.

Therefore, the purpose of this study is to identify the difference in the quality of life of the divorced elderly and the difference in quality of life through comparison with the married elderly by combining the Korea Welfare Panel 2013 and 2018 data. First, is the marriage status of the elderly changing? Second, does the quality of life of elderly divorced changed? Third, is there a difference in quality of life between the divorced elderly and married elderly after 5 years, depending on the divorce in 2013 ?

\section{Materials and Methods \\ Data and Subject}

In this study, the 8th wave of Korea Welfare Panel Data 2013 and the 13th wave of 2018 were used (Korea Welfare Panel Study, 2019). A total of 3,198 people (3,049 married and 149 divorced) were selected and analyzed among the elderly aged 60 and over in 2013. Bereaved, remarried, and unmarried were excluded from the analysis.

\section{Characteristics of subject}

Males were 1,622 (50.7\%) and females were 1,576 (49.3\%). The most common was elementary school (41.6\%), and $59.5 \%$ were religious. $94.3 \%$ were married couples or 3rd generation households, and $33.5 \%$ were the elderly living in urban areas.

\section{Measurement}

The variables selected to achieve the purpose of this study were shown in Table 1, and the higher the score, the higher the tendency.

\section{Table 1 : Instrument}

\begin{tabular}{|c|c|c|c|}
\hline \multicolumn{2}{|l|}{ Variables } & Measurement & Reliability \\
\hline \multirow{2}{*}{$\begin{array}{l}\text { Physical } \\
\text { health }\end{array}$} & Subjective Health Status & Single item, 5-point Likert & \\
\hline & Alcohol dependence & 3 items, 5 points Likert & $.940(13 y r), .963(18 y r)$ \\
\hline $\begin{array}{l}\text { Economic } \\
\text { condition }\end{array}$ & Income satisfaction & Single item, 5-point Likert & \\
\hline \multirow{3}{*}{$\begin{array}{l}\text { Family } \\
\text { Relations }\end{array}$} & $\begin{array}{ll}\text { Family } & \text { relationship } \\
\text { satisfaction } & \\
\end{array}$ & Single item, 5-point Likert & \\
\hline & Child relationship satisfaction & Single item, 5-point Likert & \\
\hline & Family conflict & 5 items, 5 points Likert & $.787(13 y r), .826(18 y r)$ \\
\hline \multirow{2}{*}{$\begin{array}{l}\text { Social } \\
\text { activity }\end{array}$} & $\begin{array}{ll}\text { Social } & \text { relationship } \\
\text { satisfaction } & \\
\end{array}$ & Single item, 5-point Likert & \\
\hline & Leisure life satisfaction & Single item, 5-point Likert & \\
\hline \multirow{3}{*}{$\begin{array}{l}\text { Mental } \\
\text { Health }\end{array}$} & Depression & $\begin{array}{l}\text { CESD, } 10 \text { items, } 4 \text { points } \\
\text { Likert }\end{array}$ & $.961(13 y r), .964(18 y r)$ \\
\hline & Self-esteem & $\begin{array}{l}\text { Rosenberg's self-esteem } \\
\text { scale, } 10 \text { questions, } 4 \text { points } \\
\text { Likert }\end{array}$ & $.931(13 y r), .945(18 y r)$ \\
\hline & Life satisfaction & Single item, 5-point Likert & \\
\hline
\end{tabular}

\section{Statistic method}

The frequency, reliability, cross tab, paired t-test and analysis of covariance (ANCOVA) were performed using SPSS 21.0.

\section{Results}

Changes in the marriage status of the elderly

In order to examine the change in the marital status of the elderly, I analyzed the marital status in 2018 
according to the marital status in 2013 (married vs. divorced) using the cross analysis in Table 2. As shown in Table 2, the results are statistically significant. However, it is reasonable to assume that the marital status of the elderly tends to be maintained rather than fluctuated. Except for bereavement, both groups seem to have little change in marriage status.

Table 2 : Changes in the marriage status of the elderly $<n=3,198>$

\begin{tabular}{|c|c|c|c|c|c|c|c|c|c|}
\hline & & & \multicolumn{5}{|c|}{ Marriage status_18yr } & \multirow{2}{*}{ total } & \multirow{2}{*}{ chi-square } \\
\hline & & & Married & Bereavement & Divorce & Separation & Others & & \\
\hline \multirow{4}{*}{$\begin{array}{l}\text { Marriage } \\
\text { status_ } \\
13 y r\end{array}$} & Marriod & $\mathrm{N}$ & 2,670 & 334 & 21 & 8 & 16 & 3,049 & \multirow{4}{*}{$2477.943^{* * *}$} \\
\hline & IMarried & $\%$ & $87.6 \%$ & $11.0 \%$ & $.7 \%$ & $0.3 \%$ & $.5 \%$ & $100.0 \%$ & \\
\hline & Divorced & $\mathrm{N}$ & 1 & 11 & 134 & 3 & 0 & 149 & \\
\hline & Div viceca & $\%$ & $0.7 \%$ & $7.4 \%$ & $89.9 \%$ & $2.0 \%$ & $0.0 \%$ & $100.0 \%$ & \\
\hline
\end{tabular}

${ }^{* * *} \mathrm{p}<.001$

\section{Changes in the quality of life of the divorced elderly}

A paired t test was conducted to examine the changes in the quality of life of divorced elderly people in Table 3. As a result, income satisfaction increased and family relationship satisfaction, child relationship satisfaction, leisure life satisfaction, and life satisfaction improved. Therefore, it can be seen that the quality of life of the elderly who are divorced changed positively in 2013.

\section{Table 3 : Changes in the quality of life of the divorced elderly} $<\mathrm{n}=149>$

\begin{tabular}{|c|c|c|c|c|}
\hline & & M & S.D & paired-t value \\
\hline \multirow{4}{*}{$\begin{array}{l}\text { Physical health } \\
\text { change }\end{array}$} & Subjective Health Status_13yr & 3.19 & .961 & \multirow{2}{*}{.565} \\
\hline & Subjective Health Status_18yr & 3.14 & .87 & \\
\hline & Alcohol dependence_13yr & 1.24 & .551 & \multirow{2}{*}{-.772} \\
\hline & Alcohol dependence_18yr & 1.40 & 1.364 & \\
\hline \multirow{2}{*}{$\begin{array}{l}\text { Economic } \\
\text { condition }\end{array}$} & Income satisfaction_13yr & 2.34 & 889 & \multirow{2}{*}{$-3.280^{* * *}$} \\
\hline & Income satisfaction_18yr & 2.64 & 894 & \\
\hline \multirow{6}{*}{$\begin{array}{l}\text { Family } \\
\text { Relations }\end{array}$} & Family relationship satisfaction_13yr & 3.05 & 957 & \multirow{2}{*}{$-2.305^{*}$} \\
\hline & Family relationship satisfaction_18yr & 3.25 & 914 & \\
\hline & Child relationship satisfaction_13yr & 3.33 & 2.078 & \multirow{2}{*}{$-2.293^{* *}$} \\
\hline & Child relationship satisfaction_18yr & 3.68 & 2.256 & \\
\hline & Family conflict_13yr & 1.40 & 866 & \multirow{2}{*}{.978} \\
\hline & Family conflict_18yr & 1.33 & 819 & \\
\hline \multirow{4}{*}{ Social activity } & Social relationship satisfaction_13yr & 3.47 & 848 & \multirow{2}{*}{-.635} \\
\hline & Social relationship satisfaction_13yr & 3.51 & 697 & \\
\hline & Leisure life satisfaction_13yr & 3.05 & 820 & \multirow{2}{*}{$-1.901^{*}$} \\
\hline & Leisure life satisfaction_18yr & 3.21 & 832 & \\
\hline \multirow{6}{*}{ Mental Health } & Depression_13yr & 1.78 & 440 & \multirow{2}{*}{-.658} \\
\hline & Depression_18yr & 1.83 & .953 & \\
\hline & Self-esteem_13yr & 2.76 & 469 & 1533 \\
\hline & Self-esteem_18yr & 2.88 & .8529 & 1.533 \\
\hline & Life satisfaction_13yr & 3.12 & .713 & $-1943^{*}$ \\
\hline & Life satisfaction_18yr & 3.26 & .724 & -1.943 \\
\hline
\end{tabular}

\section{Quality of life differences after 5 years by marital status (Married vs. Divorced)}

The analysis of covariance (ANCOVA) was used to analyze the difference in quality of life in 2018 according to the marital status in 2013 (divorced vs. married). The 2013 quality of life score was controlled. In all analyzes, Levene's Test for Equality of Error Variances was not significant, confirming homogeneity.

As a result of analyzing the differences in the quality of life according to the divorce or not of the elderly, 
significant differences were found in all variables except subjective health status, alcohol dependence among physical health, and depression among mental health status in Table 4. That is, in 2013, divorced elderly people had lower income satisfaction, family relationship satisfaction, child relationship satisfaction, social relationship satisfaction, leisure life satisfaction, and family conflict than those who were married in 2018. Self-esteem and life satisfaction were also lower. Therefore, after five years, except for family conflict, divorced elderly people had lower quality of life than married elderly people did.

Table 4 : Quality of life differences after five years by marital status (Married vs. Divorced) $<\mathrm{n}=3,198>$

\begin{tabular}{|c|c|c|c|c|c|c|c|c|c|}
\hline $18 \mathrm{yr}$ & & $\begin{array}{l}\text { Marital } \\
\text { status_ } \\
13 y r\end{array}$ & $\mathrm{~N}$ & M & S.D & Source & $\begin{array}{l}\text { Type III } \\
\text { Sum of } \\
\text { Squares }\end{array}$ & $F$ & $\begin{array}{l}\text { Partial } \\
\text { Eta } \\
\text { Squared }\end{array}$ \\
\hline \multirow{7}{*}{$\begin{array}{l}\text { Physical } \\
\text { Health }\end{array}$} & \multirow{3}{*}{$\begin{array}{l}\text { Subjective } \\
\text { Health }\end{array}$} & \multirow{2}{*}{ Married } & 3,049 & \multirow{2}{*}{3.10} & \multirow{2}{*}{.892} & Corrected Model & $243.288^{\mathrm{a}}$ & $169.488^{* * *}$ & .096 \\
\hline & & & \multirow[b]{2}{*}{149} & & & Intercept & 879.537 & $1225.473^{* * *}$ & *.277 \\
\hline & & Divorce & & 3.14 & .870 & Subjective Health_13yr & 243.038 & $338.630^{* * *}$ & .096 \\
\hline & & & & & & Marriage status_13yr & .000 & .000 & .000 \\
\hline & \multirow{3}{*}{$\begin{array}{l}\text { Alcohol } \\
\text { dependen } \\
\text { ce }\end{array}$} & \multirow{2}{*}{ Married } & \multirow{2}{*}{604} & \multirow{2}{*}{1.22} & \multirow{2}{*}{1.013} & Corrected Model & $47.021^{a}$ & $23.376^{* * *}$ & .068 \\
\hline & & & & & & Intercept & 98.431 & $97.870^{* * *}$ & .133 \\
\hline & & Divorce & 39 & 1.40 & 1.364 & Alcohol dependence_13yr & 45.784 & $45.523^{* * *}$ & .066 \\
\hline & & & & & & Marriage status_13yr & 1.444 & 1.436 & .002 \\
\hline \multirow{3}{*}{$\begin{array}{l}\text { Economic } \\
\text { Status }\end{array}$} & \multirow{3}{*}{$\begin{array}{l}\text { Income } \\
\text { satisfactio } \\
n\end{array}$} & \multirow{2}{*}{ Married } & \multirow{2}{*}{2,800} & \multirow{2}{*}{2.95} & \multirow{2}{*}{.855} & Corrected Model & $149.862^{\mathrm{a}}$ & $108.899^{* * *}$ & .069 \\
\hline & & & & & & Intercept & 1126.289 & $1636.863^{* * *}$ & .357 \\
\hline & & Divorce & 146 & 2.64 & \multirow[t]{2}{*}{.894} & Income satisfaction_13yr & 136.141 & $197.858^{* * *}$ & .063 \\
\hline & & & & & & Marriage status_13yr & 7.599 & $11.044^{* *}$ & .004 \\
\hline \multirow{12}{*}{$\begin{array}{l}\text { Family } \\
\text { Relations }\end{array}$} & & Married & 2800 & 382 & 565 & Corrected Model & $101.507^{\mathrm{a}}$ & $155.633^{* * *}$ & .096 \\
\hline & Family & & & & & Intercept & 683.920 & $2097.200^{* * *}$ & 416 \\
\hline & 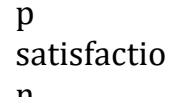 & Divorce & 146 & 3.25 & .914 & $\begin{array}{l}\text { Family relationship } \\
\text { satisfaction_13yr }\end{array}$ & 56.389 & $172.914^{* * *}$ & .055 \\
\hline & & & & & & Marriage status_13yr & 20.467 & $62.760^{* * *}$ & 021 \\
\hline & & Morrind & 2000 & & & Corrected Model & $1220.004^{a}$ & $416.755^{* * *}$ & 215 \\
\hline & Child & indinter & I L,O & 0.01 & 1.240 & Intercept & 1541.254 & $1052.990^{* * *}$ & .257 \\
\hline & s & Divorce & 148 & 3.68 & 2.256 & $\begin{array}{l}\text { Child } \\
\text { satisfaction_13yr }\end{array}$ & 747.543 & $510.724^{* * *}$ & 144 \\
\hline & & & & & & Marriage status_13yr & 130.816 & $89.374^{* * *}$ & 029 \\
\hline & & Marriod & 2010 & 151 & 0171 & Corrected Model & $35.885^{\mathrm{a}}$ & $76.974^{* * *}$ & .271 \\
\hline & & & & & & Intercept & 276.434 & $1185.904^{* * *}$ & *.038 \\
\hline & conflict & Divorce & 149 & 1.33 & 0.819 & Family onflict_13yr & 29.683 & $127.341^{* * *}$ & .005 \\
\hline & & & & & & Marriage status_13yr & 4.059 & $17.411^{* * *}$ & .003 \\
\hline & & Marriod & 2800 & 366 & 609 & Corrected Model & $27.838^{\mathrm{a}}$ & $37.835^{* * *}$ & .025 \\
\hline & relationshi & i Vidrieu & $1<, 000$ & 0.00 & .009 & Intercent & 784184 & $2131578^{* * *}$ & 420 \\
\hline & $\begin{array}{l}\text { satisfactio } \\
\mathrm{n}\end{array}$ & Divorce & 146 & 3.51 & .697 & $\begin{array}{l}\text { Social relationship } \\
\text { satisfaction } 13 y r\end{array}$ & 24.810 & $67.439^{* * *}$ & .022 \\
\hline
\end{tabular}




\begin{tabular}{|c|c|c|c|c|c|c|c|c|c|}
\hline & & & & & & Marriage status_13yr & 1.434 & $3.898^{*}$ & 001 \\
\hline & \multirow{3}{*}{$\begin{array}{l}\text { Leisure } \\
\text { life } \\
\text { satisfactio } \\
\mathrm{n}\end{array}$} & \multirow{2}{*}{ Married } & \multirow{2}{*}{2,800} & \multirow{2}{*}{3.38} & .721 & Corrected Model & $45.821^{\mathrm{a}}$ & $44.532^{* * *}$ & .029 \\
\hline & & & & & \multirow[b]{2}{*}{.832} & Intercept & 1127.586 & $2191.718^{* * *}$ & *.427 \\
\hline & & Divorce & 146 & 3.21 & & $\begin{array}{l}\text { Leisure } \\
\text { satisfaction_13yr }\end{array}$ & 42.052 & $81.737^{* * *}$ & .027 \\
\hline & & & & & & Marriage Status_13yr & 2.469 & $4.799^{*}$ & .002 \\
\hline \multirow{12}{*}{$\begin{array}{l}\text { Mental } \\
\text { Health }\end{array}$} & \multirow{4}{*}{$\begin{array}{l}\text { Depressio } \\
\mathrm{n}\end{array}$} & \multirow{2}{*}{ Married } & \multirow{2}{*}{2,899} & \multirow{2}{*}{1.74} & \multirow{2}{*}{1.088} & Corrected Model & $48.911^{\mathrm{a}}$ & $21.184^{* * *}$ & .014 \\
\hline & & & & & & Intercept & 839.963 & $727.581^{* * *}$ & 193 \\
\hline & & Divorce & 148 & 1.83 & \multirow{2}{*}{.953} & Dipression_13yr & 47.787 & $41.393^{* * *}$ & 013 \\
\hline & & \multirow{3}{*}{ Married } & & & & Marriage status_13yr & .807 & .699 & .000 \\
\hline & \multirow{3}{*}{$\begin{array}{l}\text { Self- } \\
\text { esteem }\end{array}$} & & \multirow{2}{*}{2,899} & \multirow{2}{*}{3.11} & \multirow{2}{*}{.904} & Corrected Model & $27.658^{\mathrm{a}}$ & $17.142^{* * *}$ & 011 \\
\hline & & & & & & Intercept & 1207.971 & $1497.308^{* * *}$ & .330 \\
\hline & & Divorce & 148 & 2.88 & \multirow[t]{2}{*}{.852} & Self-esteem_13yr & 20.004 & $24.796^{* * *}$ & .008 \\
\hline & & & & & & Marriage status_13yr & 5.800 & $7.189^{* *}$ & .002 \\
\hline & \multirow{4}{*}{$\begin{array}{l}\text { Life } \\
\text { satisfactio } \\
\text { n }\end{array}$} & Married & 2800 & 351 & 639 & Corrected Model & $72.994^{\mathrm{a}}$ & $92.956^{* * *}$ & .059 \\
\hline & & (1) & & ו & & Intercept & 615.656 & $1568.041^{* * *}$ & .348 \\
\hline & & Divorce & 146 & 3.26 & .724 & Satisfaction_13yr & 64.241 & $163.618^{* * *}$ & .053 \\
\hline & & & & & & Marriage status_13yr & 3.377 & $8.602^{* *}$ & .003 \\
\hline
\end{tabular}

${ }^{*} \mathrm{p}<.05,{ }^{* *} \mathrm{p}<.01,{ }^{* * *} \mathrm{p}<.001$

\section{Results}

In this study, a panel analysis was conducted by combining the 2013 Korea Welfare Panel data and 2018 data to examine the differences in the quality of life of the divorced elderly and the difference between the married elderly. To this end, I analyzed data from 3,049 married elderly and 149 divorced seniors among 3,098 married persons over 60 years of age in the 8th Wave of Korea Welfare Panel 2013. In summarizing the main findings, the following are discussed

First, the marriage status of the elderly did not change significantly. Although it was statistically significant, except for the death of a spouse, a representative case of old age, only $1 \%$ of married elderly and $2.7 \%$ of divorced seniors had a change in marriage status such as divorce, remarriage, and separation. Nevertheless, it is socially suggestive that the divorced elderly are still divorced.

Second, divorced elderly people were adjusting to divorce after 5 years. This is partly in agreement with the findings (Dales L., 2014; Makidon A et al., 2013; Moshavi S, 2000) that life satisfaction of elderly women increased after divorce. However, family relationships are important in adaptation after divorce of the elderly, but they are seriously affected by changes in their relationship with their children, and they have difficulty adjusting to their jobs after quitting or being fired after divorce (Lee HS, 2108). Lee (2018)'s study is different from the results of this study because it is only for the men elderly. Therefore, it is necessary to derive clear results through comparison between men and women.

Third, as a result of comparing the quality of life in 2018 according to the divorce status in 2013, the quality of life of the divorced elderly was poor compared to the married elderly. Therefore, the elderly have adapted to their life after divorce, but their quality of life is lower than that of the elderly who still have a spouse. There are various tangible and intangible resources that can be obtained through marriage, and the divorced elderly can be interpreted as lacking these resources. Therefore, it is important to find ways to improve the quality of life after divorce. First, efforts are needed to reduce negative social perceptions about divorce in old age. Of course, the perception of the divorce of the elderly is changing positively every year. Nevertheless, considering the fact that opposition to divorce is quite high at $59.8 \%$ (Kostat b, 2019), it is necessary to change the social perception of divorce as a personal choice. Second, alternative family linkages are needed. Since the role of the community has a significant impact on divorce adaptation (Naoi $\mathrm{T}, 2006)$, there is a need for confrontational programs for divorced seniors and family-building projects through religious or community links.

On the other hand, divorced elderly were also less likely to have family conflicts after five years than 
married elderly. Interpretation is possible in two ways. First, they would try to avoid conflicts or conflicts with family members remaining after divorce, which may have resulted in a lower family conflict. Second, the number of family members who will experience conflict after divorce may be small. In other words, living alone after divorce or living with one or two family members, it would have reduced the factor of family conflict. However, the first interpretation that the divorced elderly should have tried to reduce the conflict with the family remaining after divorce, considering the positive change in family relationship satisfaction or child relationship satisfaction after divorce, is more valid.

\section{Conclusion}

Through this study, I will draw three conclusions: First, the change in marital status of the elderly was not significant. Second, the divorced elderly were adjusting to life after divorce. Third, the divorced elderly had a lower quality of life compared to the married elderly.

Unlike previous studies that dealt with the adaptation of Korean elderly people after divorce from a fragmentary perspective, this study revealed that the elderly are adapting after divorce by utilizing largescale survey data. Nevertheless, the divorce period could not be determined due to the limitations of using secondary data. In other words, there is a limitation that it is impossible to determine when an elderly person who was divorced at the time in 2013, indicating that there is a problem with the generalization of research results. Also, in this study, it was not analyzed separately between men and women. Since the differences between men and women in post-divorce adaptation are evident, especially in the case of the East, where Confucian ideas are deep, it is suggested that a research design should be taken into account.

\section{Acknowledgment}

This research is funded by the Hanseo University, Republic of Korea.

\section{References}

- Andreevna I.S., 2015. Social Foundations of divorce in old age. Modern Research of Social Problems, Vol. 2, pp. 1-11.

- Anuara N.H, Mahmudb Z. and Mohd D.N.F., 2019. Informal caregiving of senior parents in Malaysia: Issues \& Counselling Needs. International Journal of Innovation, Creativity and Change, Vol. 5, no 6, pp. 408420.

- Dales L. 0., 2014. Singlehood and agency in Japan. Journal Asian Studies Review, Vol. 38, no. 2, pp. 224242.

- Hetherington E. M . and Kelly J., 2002. For better or for worse: divorce reconsidered. WW Norton \& Company.

- Jo Y.S., 2014. (A) study on the factors that has an effect on divorce intention of aged spouses : centering on the comparison of aged men and aged women. [Doctorial Thesis ]. Baekseok University. [online] http://www.riss.kr.library.hanseo.ac.kr:8000/search/detail/DetailView.do?

p_mat_type=be54d9b8bc7cdb09\&control_no=f40bb963775956fcffe0bdc3ef48d419. Available at: [Accessed 1 Oct. 2020].

- Kitson G.C. and Morgan L.A., 1990. The multiple consequences of divorce: a decade review. Journal of Marriage and Family, Vo. 52, no. 4, pp. 913-924.

- Korea Welfare Panel Study, 2019. Korea Welfare Panel Data. [online] https://www.koweps.re.kr:442/data/data/list.do. Available at: [Accessed 4 May 2020 ].

- Kostat a., 2019. 2018 Marriage and divorce statistics. [online]. http://www.index.go.kr /potal /main /EachDtlPageDetail.do?idx_cd=1579. Available at: [Accessed 30 May 2020 ].

- Kostat b., 2019. Elderly statistics. [online] http://kostat.go.kr/portal/korea/kor_nw/1/1/ index.board? bmode $=$ read\&aSeq $=385322$. Available at: [Accessed 30 May 2020 ].

- Lee H. S., 2015. A case study on the elderly woman who has divorced. Journal of Welfare for the Aged, Vol. 68, pp. 85-106. [online] http://www.riss.kr/search/detail/DetailView.do?p_mat_type= 1a0202e37d52c72d\& control_no=0d43b6381a492fa47ecd42904f0c5d65. Available at: [Accessed 9 May 2020 ].

- Lee H. S., 2018 The adaptation process of the elderly men after elderly divorce - based on the elderly divorce studies in Korea and Japan -. Japanese Cultural Studies, Vol. 67, pp. 293-330. [online] http://www.riss.kr/search/detail/DetailView.do?p_mat_type=1a0202e37d52c72d controlno=e4cb0496d6ff110bb7998d826d417196. Available at: [Accessed 23 May 2020 ].

- Lillard L. A. and Waite L. J., 1995. Til death do us part: Marital disruption and mortality. American 
Journal of Sociology. Vol. 100, no 5, pp. 1131-1156.

- Makidon Y.P., 2013. A study of baby boomer divorced women and their divorce experiences. Michigan State University, ProQuest Dissertations Publishing.

- Moon J.H, Kim E.R, Park Y.G. and Kim M.R., 2014. Qualitative case study on elderly women`s initial adaptive experiences after divorce: focused on the first two years after divorce. The Korean Association of Family Welfare. Vol. 19, no. 4. pp. 693-713. [online] http://www.riss.kr.library.hanseo.ac.kr: $8000 /$ search/detail/DetailView.do?p_mat_type $=$ $1 \mathrm{a} 0202 \mathrm{e} 37 \mathrm{~d} 52 \mathrm{c}$ 72d\&control_no=8d06085878a4c1c87f7a54760b b41745. Available at: [Accessed 25 May 2020 ].

- Morgan L.A., 1991. After marriage end. Newbury Park, CA: Sage.

- Moshavi S., 2000. Japan's older wives learn to leave. Boston Globe; Boston, Mass.

- Naoi T., 2006. Assisting post divorce parental relationships in Japan: learning from programs in the United States. Alliant International University, San Francisco Bay, ProQuest Dissertations Publishing.

- Park H. and Raymo J. M., 2013. Divorce in Korea: trends and educational differentials. Journal of Marriage and the Family; Minneapolis, Vol. 75, no 1, pp. 110-126. 